\title{
Prenatal nitrosatable prescription drug intake, drinking water nitrate, and the risk of stillbirth: a register- and population-based cohort of Danish pregnancies, 1997-2017
}

Anne Marie Ladehoff Thomsen ${ }^{1,2^{*}} \mathbb{C}$, Cecilia Høst Ramlau-Hansen², Jörg Schullehner ${ }^{2,3,4}$, Ninna Hinchely Ebdrup ${ }^{2}$, Zeyan Liew ${ }^{5,6}$, Vanessa Coffman ${ }^{7}$, Leslie Stayner ${ }^{7}$, Birgitte Hansen ${ }^{3}$ and Jørn Olsen ${ }^{8}$

\begin{abstract}
Background: Nitrosatable drugs commonly prescribed during pregnancy can react with nitrite to form $N$-nitroso compounds which have been associated with an increased risk of stillbirth. Whether maternal residential drinking water nitrate modifies this association is unknown. We investigated, if household drinking water nitrate was associated with stillbirth, and if it modified the association between nitrosatable prescription drug intake and the risk of stillbirth.
\end{abstract}

Methods: We conducted an individual-level register- and population-based cohort study using 652,810 women with the first recorded singleton pregnancy in the Danish Medical Birth Registry between 1997 and 2017. Nitrosatable drug exposure was recorded by use of the Danish National Patient Registry defined as women with a first redeemed prescription of a nitrosatable drug the first 22 weeks of pregnancy. The reference group was women with no redeemed prescription of a nitrosatable drug in this period. The average individual drinking water nitrate concentration level $(\mathrm{mg} / \mathrm{L})$ was calculated in the same period. We categorized nitrosatable drugs as secondary amines, tertiary amines, and amides. Cox hazard regression was used to estimate crude and adjusted hazard ratios with 95\% confidence intervals for stillbirth stratified into five categories of nitrate concentrations: $\leq 1 \mathrm{mg} / \mathrm{L},>1-\leq 2 \mathrm{mg} / \mathrm{L},>2-\leq 5 \mathrm{mg} / \mathrm{L}$, $>5$ - $\leq 25 \mathrm{mg} / \mathrm{L}$, and $>25 \mathrm{mg} / \mathrm{L}$.

Results: Drinking water nitrate exposure in the population was not associated with the risk of stillbirth. Among 100,244 women who had a nitrosatable prescription drug redeemed $\leq 22$ weeks of pregnancy of pregnancy, 418 (0.42\%) had a stillbirth compared to 1993 stillbirths (0.36\%) among 552,566 referent women. Women with any nitrosatable prescription drug intake and $>1-\leq 2 \mathrm{mg} / \mathrm{L}$ nitrate concentration had an increased risk of stillbirth [adjusted hazard ratio 1.55 (95\% confidence interval, 1.15-2.09)] compared with referent women. In the stratified analyses, the highest risk of stillbirth was found among women with secondary amine intake and $>25 \mathrm{mg} / \mathrm{L}$ nitrate concentrations [adjusted hazard ratio $3.11(95 \% \mathrm{Cl}, 1.08-8.94)$ ].

Conclusions: The association between nitrosatable prescription drug intake and the risk of stillbirth may depend on the level of nitrate in household drinking water. Evaluations of the effect of nitrosatable drug intake on perinatal outcomes might consider nitrate exposure from drinking water.

\footnotetext{
*Correspondence: anlade@rm.dk

2 Department of Public Health, Aarhus University, Aarhus, Denmark

Full list of author information is available at the end of the article
} permits use, sharing, adaptation, distribution and reproduction in any medium or format, as long as you give appropriate credit to the original author(s) and the source, provide a link to the Creative Commons licence, and indicate if changes were made. The images or other third party material in this article are included in the article's Creative Commons licence, unless indicated otherwise in a credit line to the material. If material is not included in the article's Creative Commons licence and your intended use is not permitted by statutory regulation or exceeds the permitted use, you will need to obtain permission directly from the copyright holder. To view a copy of this licence, visit http://creativecommons.org/licenses/by/4.0/. The Creative Commons Public Domain Dedication waiver (http://creativeco mmons.org/publicdomain/zero/1.0/) applies to the data made available in this article, unless otherwise stated in a credit line to the data. 
Keywords: Nitrosatable drug, Amine, Amide, N-nitroso compounds, Stillbirth, Drinking water nitrate, Cohort study

\section{Background}

An estimated 15-24\% of U.S. and Danish women use a nitrosatable drug at some point in time during pregnancy, including common drugs such as antibiotics, asthma medications and antiemetics [1,2]. This broad range of medications contain compounds such as secondary amines, tertiary amines, and amides. Nitrate $\left(\mathrm{NO}_{3}{ }^{-}\right)$from drinking water and other nitrate sources is converted to nitrite $\left(\mathrm{NO}_{2}^{-}\right)$in the human body and subsequently can react with amines and amides in the gastrointestinal tract to form teratogenic $\mathrm{N}$-nitroso compounds (NOCs) under highly acidic environments as in the stomach. NOCs are formed to a greater extent, if the concentration of nitrosating agent is high [3, 4]. NOC formation in the maternal stomach and the subsequent transplacental transmission to the fetus is the most likely source of prenatal exposure to NOCs [57]. The teratogenic effect of NOCs may be caused by abnormal development through DNA alkylation [8].

While prenatal nitrosatable drug exposure may cause congenital malformations and preterm birth, few studies have examined the relation between nitrosatable drugs and stillbirth [2, 9-13]. Stillbirth is a rare adverse pregnancy outcome, in Denmark and in other high-income countries, with an estimated rate of 2-5 per 1000 births [14]. The etiology of stillbirth is mainly unknown, but impaired placental function is as a possible major underlying risk factor. Other risk factors include advanced parental age, primiparity, high body mass index (BMI), and maternal smoking during pregnancy, infections, and diseases such as diabetes and hypertension [15-19]. Our results from an earlier study indicated that nitrosatable prescription drug intake (e.g. use of penicillin for infection or terbutaline for asthma) during the first 22 weeks of pregnancy may increase the risk of stillbirth. However, we lacked data on sources of $\mathrm{NO}^{-}$exposure that may modify the association between nitrosatable drug exposure and the risk of stillbirth, including data from drinking water sources [2].

Danish tap water is based completely on groundwater with farming contributing to $\mathrm{NO}_{3}{ }^{-}$contamination [20]. Roughly $5 \%$ of the Danish population is exposed to tap water concentrations $>25 \mathrm{mg} / \mathrm{L} \mathrm{NO}_{3}{ }^{-}$, with levels having decreased during the last decades, because of national agricultural nitrogen regulation, local action plans, and infrastructural changes [21]. To protect against infant methemoglobinemia, European Union regulatory limits have been set to $50 \mathrm{mg} / \mathrm{L} \mathrm{NO}_{3}{ }^{-}$in drinking water and a similar level has been set in the U.S. (44 mg/L $\left.\mathrm{NO}_{3}{ }^{-}\right) . \mathrm{NO}_{3}{ }^{-}$exposure below the current regulatory limits has, however, been associated with miscarriage, intrauterine growth restriction, stillbirth, premature birth, and childhood cancer [22-26].

In this study, we examined whether $\mathrm{NO}_{3}{ }^{-}$in maternal residential drinking water was associated with the risk of stillbirth, and if it modified the association between prenatal nitrosatable prescription drug intake and the risk of stillbirth. Our hypothesis was that the risk of stillbirth would be higher among women who had a nitrosatable prescription drug redeemed during pregnancy and whose residential water $\mathrm{NO}_{3}{ }^{-}$concentrations were $>25 \mathrm{mg} / \mathrm{L}$ compared to those, who did not redeem a nitrosatable prescription drug.

\section{Methods \\ Study design and population}

We conducted an individual-level register- and population-based cohort study using data from the Danish Civil Registration System, the Danish Medical Birth Registry, and the Danish National Prescription Register [27-29]. All women with a registered singleton and first recorded pregnancies in Denmark between 1997 and 2017 were identified from the Danish Medical Birth Registry $(n=707,467)$, regardless of their previous pregnancies before the study period. After excluding 54,657 births with coding errors on gestational length, maternal drinking water estimates from private wells, or missing drinking $\mathrm{NO}^{-}$data, our study population included a total of 652,810 mother-child dyads.

\section{Data sources}

The registers utilized in this study offer an exceptional resource with their depth and breadth of data collected. The unique civil personal registration (CPR) number, which has been assigned to nearly all (>99\%) Danish residents since 1968, was used as key identifier to link data between the national registries. In addition, the Danish Civil Registration System holds weekly updated information on date of birth, sex, and residential history [27].

The Danish Medical Birth Registry has information on all births in Denmark from 1973 onwards, including the CPR number of the child, the mother, and the registered father. It also holds information on gestational age based mainly on ultrasound measures and occasionally on last menstrual period, height and weight at birth, birth date, birth outcome (liveborn or death and cause of death), sex, parental age, and number of previous births [28]. 
The Danish National Prescription Register holds information on redemption of prescribed medication. This register has individual-level data on all prescribed drugs dispensed at any pharmacy in Denmark since 1995 [29]. Pharmacies are required to register all redeemed prescriptions, which are coupled with the reimbursement of expenses from the state. This ensures highly accurate prescription data and completeness has been estimated to be $>97 \%$ [30].

\section{Nitrosatable drug assessment}

Detailed procedures for classifying as nitrosatable and for categorizing them based on their functional groups and indications have been discussed in detail elsewhere [1]. We used nitrosatable medicinal compounds lists from published literature to classify nitrosatability, and we included the medication reported to be used between 1997 and 2017 [1, 4, 31]. We included only the medication reported to be used in our population in the study period. All drugs were categorized on the basis of the presence of secondary amine, tertiary amine, and amide functional groups. These categories are not mutually exclusive.

We identified the Anatomical Therapeutic Chemical codes for the categorized drugs and matched these with codes in the Danish National Prescription Register, which also contained information on the date of redemption of the prescription (see Supplementary Table S1 for a complete list of included nitrosatable drugs). All analyses are based on the first nitrosatable prescription drug redeemed from the estimated first day in the last menstrual period (week 0) until the end of week 22 of pregnancy. Women with no redeemed nitrosatable prescription drug during this period were defined as the unexposed comparison.

\section{Drinking water $\mathrm{NO}^{-}$assessment}

The Danish national geodatabase Jupiter holds drinking water monitoring data [32]. The maternal residential drinking water $\mathrm{NO}_{3}{ }^{-}$estimates build on the approach developed and described by Schullehner et al. [33]. In short, annual drinking water production volume weighted average $\mathrm{NO}_{3}{ }^{-}$concentrations were calculated for public water supply areas and spatio-temporally linked with the geocoded residential history of every person registered in the Danish Civil Registration System. For this study, $107,821 \mathrm{NO}_{3}^{-}$samples in 3635 public waterworks between 1993 and 2017 were extracted. $\mathrm{NO}_{3}{ }^{-}$levels were imputed by interpolation for missing years, if a $\mathrm{NO}_{3}{ }^{-}$sample was available within 3 years, otherwise the year was assigned as missing $\mathrm{NO}_{3}{ }^{-}$. Individual exposure for each woman was computed as the timeweighted average concentration during pregnancy taking into account changes in residence during pregnancy [34]. The average $\mathrm{NO}_{3}{ }^{-}$concentration level $(\mathrm{mg} / \mathrm{L})$ for each woman was calculated in the period from the estimated first day in the last menstrual period (week 0) until the end of week 22. As private wells are not monitored to the same degree as public supplies, users of private wells (approximately 3\% of Danish residents) were excluded from the study population.

\section{Stillbirth assessment}

Before 1 January 2004, stillbirth in Denmark was defined as the birth of a non-vital fetus after $\geq 28$ completed weeks of pregnancy. In 2004 the cut point changed to 22 completed weeks, as in most other countries [35]. To harmonize the study population, we extracted all registered stillbirths born at 22 weeks of pregnancy or later between 1997 and 2017. Pregnancy period was based on the child's date of birth and gestational age at birth in days.

\section{Statistical analyses}

We investigated, if drinking water $\mathrm{NO}_{3}{ }^{-}$in the population was associated with stillbirth by using Cox proportional hazards model with gestational age (days) as the underlying time scale. We estimated crude and adjusted hazard ratios (aHRs) and corresponding 95\% confidence intervals (CIs) for stillbirth in relation to five categories of residential drinking water $\mathrm{NO}_{3}{ }^{-}$concentrations defined a priori according to those previously described cut-off in Coffman et al. 2021 [25]. The first category consists of exposures below the uppermost limit of detection at $1 \mathrm{mg} / \mathrm{L}$. The four other categories were categorized as following: $>1-\leq 2 \mathrm{mg} / \mathrm{L}, \quad>2-\leq 5 \mathrm{mg} / \mathrm{L}, \quad>5-\leq 25 \mathrm{mg} / \mathrm{L}$ and $>25 \mathrm{mg} / \mathrm{L}$.

We also examined whether the association between any nitrosatable prescription drug intake and stillbirth was modified on the multiplicative scale by drinking water $\mathrm{NO}_{3}{ }^{-}$stratified into the five categories of $\mathrm{NO}_{3}{ }^{-}$concentrations. In a secondary analysis, secondary amine, tertiary amine, and amide intake were also stratified into the five categories of $\mathrm{NO}_{3}{ }^{-}$concentrations to further examine effect medication by drinking water nitrate in these functional groups.

Adjusted analyses included the following covariates identified a priori using existing literature and directed acyclic graphs and obtained from the Danish Medical Birth Registry: parity (continuous), urbanicity of maternal address at birth (five categories), maternal age at delivery (continuous), smoking during pregnancy (yes/ no), pregestational BMI (continuous), and highest level of maternal education (six categories) and maternal occupation (seven categories), which were based on the International Standard Class of Occupation and Education codes (ISCO-88 and ISCED) obtained from Statistics Denmark 
$[15,19,36]$. The proportional hazard assumption and the linearity of covariates were accepted. All analyses were performed using Stata, version 15.0 (StataCorpLP, College Station, TX, USA) and R 4.0 (R Core Team (2021). $\mathrm{R}:$ A language and environment for statistical computing. R Foundation for Statistical Computing, Vienna, Austria).

\section{Results}

Our study included 652,810 women with a singleton and first recorded pregnancy leading to birth from 1997 to 2017, regardless of their previous pregnancies before the study period. Among these women, 100,244 (15.3\%) had at least one redeemed prescription of a nitrosatable drug during the first 22 weeks of pregnancy. Among those prescribed, the most commonly redeemed drugs were phenoxymethylpenicillin (38.5\%), metoclopramide (22.0\%), and terbutaline (7.4\%) (data not shown). Women, who had a nitrosatable prescription drug intake were generally younger, had a higher BMI, were parous, smoked, were less educated, were more often unemployed, and lived more often in rural and provincial towns compared with referent women, irrespective of $\mathrm{NO}_{3}{ }^{-}$(Table 1).

We found no association between $\mathrm{NO}_{3}{ }^{-}$exposure levels in the population and risk of stillbirth in crude and adjusted analyses (Table 2). Among the 100,244 women who had a nitrosatable prescription drug intake during the first 22 weeks of pregnancy, $418(0.42 \%)$ had a recorded stillbirth, while among the 552,566 unexposed women $1993(0.36 \%)$ stillbirths were recorded. Women with any nitrosatable prescription drug intake $>1-\leq 2 \mathrm{mg} / \mathrm{L} \mathrm{NO}_{3}{ }^{-}$category had a higher risk of stillbirth [aHR 1.55 (95\% CI, 1.15-2.09)] compared with referent women. Higher possible risks of stillbirth among women with any nitrosatable prescription drug intake were also estimated in the three higher $\mathrm{NO}_{3}{ }^{-}$concentration categories compared with referent women, however, the risks were slightly less than those within $>1-\leq 2 \mathrm{mg} / \mathrm{L}$ category (Table 3).

We found similar results to the main analysis, when we examined secondary amines, tertiary amines, and amides stratified into the five categories of $\mathrm{NO}_{3}{ }^{-}$concentrations. Overall, the highest risk of stillbirth [aHR 3.11 (95\% CI, $1.08-8.94)]$ was found among women with a secondary amine intake and $>25 \mathrm{mg} / \mathrm{L} \mathrm{NO}_{3}{ }^{-}$concentrations compared with referent women. Among women with tertiary amine or amide intake and $>1-\leq 2 \mathrm{mg} / \mathrm{L} \mathrm{NO}_{3}{ }^{-}$exposure, the risk of stillbirth was higher with an estimated [aHR 1.79 (95\% CI, 1.18-2.69)] and an [aHR 1.45 (95\% CI, 1.02-2.06)] compared to referent women (Table 4). The associations with each of the most common drugs as exposures (phenoxymethylpenicillin, metoclopramide, terbutaline), stratified into the five categories of
$\mathrm{NO}_{3}{ }^{-}$concentrations, were similar to our main analysis (data not shown).

\section{Discussion}

To the best of our knowledge, this is the first study to examine potential effect measure modification by household $\mathrm{NO}_{3}{ }^{-}$tap water on the association between prenatal nitrosatable prescription drug intake and the risk of stillbirth. While drinking water $\mathrm{NO}_{3}{ }^{-}$concentrations were not associated with the risk of stillbirth, we found that the association between nitrosatable prescription drug intake may be modified by maternal residential drinking water $\mathrm{NO}_{3}{ }^{-}$.

Overall, we observed that the potential effect of any nitrosatable prescription drug intake during the first 22 weeks of pregnancy on the risk of stillbirth was stronger among women within the $>1-\leq 2 \mathrm{mg} / \mathrm{L} \mathrm{NO}_{3}{ }^{-}$ category, whereas comparatively lower, although still higher, risks were observed with higher exposure categories. This may be attributed to survival bias where pregnancy loss or inability to conceive among women in the highest category of exposure may obscure our results. We conditioned our analyses on survival until 22 weeks and the most susceptible fetuses to nitrosatable drug exposure in conjunction with higher levels of $\mathrm{NO}_{3}{ }^{-}$concentrations may not survive until that gestational age. If survival was influenced by the synergy of the two exposures, the magnitude of our effect may be incorrect, but likely in the correct direction [37]. In stratified analyses, the highest risk of stillbirth was found among women with a secondary amine intake in the $>25 \mathrm{mg} / \mathrm{L} \mathrm{NO}_{3}{ }^{-}$ concentration category [aHR 3.11 (95\% CI, 1.08-8.94)], however, this finding should be interpreted cautiously due to the low number of cases.

In our previous study, where we found an increased risk of stillbirth with nitrosatable prescription drug intake during the first 22 weeks of pregnancy, we adjusted for municipalities as a proxy measure for drinking water $\mathrm{NO}_{3}{ }^{-2}$. Other birth outcomes studies have focused on nitrosatable drug exposure in conjunction with dietary $\mathrm{NO}_{3}{ }^{-}$intake and risk of adverse birth outcomes finding that nitrosatable prescription drug intake coupled with dietary $\mathrm{NO}_{2}{ }^{-}$intake higher than 1.93 and $3.20 \mathrm{mg} /$ day increased the risk of preterm birth and neutral tube defects [38, 39]. Based on what is known about the endogenous formation of NOCs, and our most recent findings, it is important to take drinking water $\mathrm{NO}_{3}{ }^{-}$into account when assessing the potential harmful effects of nitrosatable drugs on the risk of adverse perinatal outcomes.

There are limitations to our analyses. Information on prescription drug exposure relied entirely on registration of dispensed prescriptions rather than intake of 
Table 1 Characteristics of the cohort of women who redeemed, and who did not redeem a nitrosatable prescription drug during the first 22 weeks of pregnancy, 1997-2017, Denmark

\begin{tabular}{|c|c|c|}
\hline \multirow[t]{2}{*}{ Characteristic } & \multicolumn{2}{|c|}{$\begin{array}{l}\text { Redeemed nitrosatable drug during the first } 22 \text { weeks of } \\
\text { pregnancy }\end{array}$} \\
\hline & $\begin{array}{l}\text { No } \\
(n=552,566)\end{array}$ & $\begin{array}{l}\text { Yes } \\
(n=100,244)\end{array}$ \\
\hline \multicolumn{3}{|l|}{ Age, y, n (\%) } \\
\hline$<19$ & $5706(1.0)$ & $1266(1.3)$ \\
\hline $19-24$ & $66,476(12.0)$ & $14,666(14.6)$ \\
\hline $24-29$ & $193,577(35.0)$ & $34,355(34.3)$ \\
\hline $29-34$ & $189,329(34.3)$ & $32,348(32.3)$ \\
\hline$>34$ & $96,972(17.5)$ & $17,541(17.5)$ \\
\hline Missing & $506(0.0)$ & $68(0.0)$ \\
\hline \multicolumn{3}{|l|}{ Body mass index, kg/m², n (\%) } \\
\hline$<18$ & $14,607(2.6)$ & $2336(2.3)$ \\
\hline $18-25$ & $192,003(34.7)$ & $27,979(27.9)$ \\
\hline $25-30$ & $55,658(10.1)$ & $10,271(10.2)$ \\
\hline$>30$ & $29,124(5.3)$ & $7361(7.3)$ \\
\hline Missing & $261,174(47.3)$ & $52,297(52.2)$ \\
\hline \multicolumn{3}{|l|}{ Parity, n (\%) } \\
\hline Nulliparous & $422,921(76.5)$ & $68,909(68.7)$ \\
\hline Primiparous & $76,403(13.8)$ & $17,930(17.9)$ \\
\hline Multiparous & $43,918(7.9)$ & $11,570(11.5)$ \\
\hline Missing & $9324(1.7)$ & $1835(1.8)$ \\
\hline \multicolumn{3}{|l|}{ Smoking during pregnancy, n (\%) } \\
\hline No & $401,154(72.6)$ & $66,726(66.6)$ \\
\hline Yes & $82,775(15.0)$ & $19,259(19.2)$ \\
\hline Missing & $68,637(12.4)$ & $14,259(14.2)$ \\
\hline \multicolumn{3}{|l|}{ Maternal level of education, $n(\%)$} \\
\hline Higher education or PhD & $58,747(10.6)$ & $6820(6.8)$ \\
\hline Middle education & $124,762(22.6)$ & $18,744(18.7)$ \\
\hline Basic education & $37,321(6.8)$ & $5834(5.8)$ \\
\hline High School or vocational & $213,658(38.7)$ & $40,075(40.0)$ \\
\hline Primary school & $101,265(18.3)$ & $26,277(26.2)$ \\
\hline Unknown & $13,584(2.5)$ & $2171(2.2)$ \\
\hline Missing & $3229(0.6)$ & $323(0.3)$ \\
\hline \multicolumn{3}{|l|}{ Maternal occupation, n (\%) } \\
\hline Owner of business & $10,267(1.9)$ & $1606(1.6)$ \\
\hline Chief executive or employee with high income & $70,443(12.7)$ & $9270(9.2)$ \\
\hline Employee with middle income & $106,673(19.3)$ & $16,453(16.4)$ \\
\hline Employee with low income & $153,572(27.8)$ & $30,148(30.1)$ \\
\hline Employee unspecified income & $81,095(14.7)$ & $14,403(14.4)$ \\
\hline Pensioners & $2301(0.4)$ & $1087(1.1)$ \\
\hline Unemployed & $127,184(23.0)$ & $27,231(27.2)$ \\
\hline Missing & $1031(0.2)$ & $46(0.0)$ \\
\hline \multicolumn{3}{|l|}{ Urbanicity of maternal address at birth, n (\%) } \\
\hline Rural areas ${ }^{\mathrm{a}}$ & $130,413(23.6)$ & $26,497(26.4)$ \\
\hline Provincial town ${ }^{b}$ & $143,405(26.0)$ & $28,956(28.9)$ \\
\hline Provincial city ${ }^{c}$ & $84,114(15.2)$ & $13,289(13.3)$ \\
\hline Suburb of capital & $63,944(11.6)$ & $12,403(12.4)$ \\
\hline Capital & $121,507(22.0)$ & 18,205 (18.2) \\
\hline Missing & $9183(1.7)$ & $894(0.9)$ \\
\hline
\end{tabular}


Table 1 (continued)

\begin{tabular}{|c|c|c|}
\hline \multirow[t]{2}{*}{ Characteristic } & \multicolumn{2}{|c|}{$\begin{array}{l}\text { Redeemed nitrosatable drug during the first } 22 \text { weeks of } \\
\text { pregnancy }\end{array}$} \\
\hline & $\begin{array}{l}\text { No } \\
(n=552,566)\end{array}$ & $\begin{array}{l}\text { Yes } \\
(n=100,244)\end{array}$ \\
\hline \multicolumn{3}{|c|}{ Household $\mathrm{NO}_{3}{ }^{-}$average concentration (mg/L), $\mathrm{n}(\%)$} \\
\hline$\leq 1$ & $128,213(23.2)$ & $23,836(23.8)$ \\
\hline$>1-\leq 2$ & $170,870(30.9)$ & $28,624(28.6)$ \\
\hline$>2-\leq 5$ & $181,868(32.9)$ & $33,501(33.4)$ \\
\hline$>5-\leq 25$ & $52,634(9.5)$ & $10,827(10.8)$ \\
\hline$>25$ & $18,981(3.4)$ & $3456(3.4)$ \\
\hline
\end{tabular}

a Municipalities in Denmark where the largest town was $<10000$ residents

b Municipalities with a town between $10000-100000$ residents

c Municipalities with town $>100000$ residents

Table 2 Hazard ratios (HRs) for stillbirth for given maternal residential drinking water nitrate concentration during the first 22 weeks of pregnancy

\begin{tabular}{|c|c|c|c|c|}
\hline \multirow{2}{*}{$\begin{array}{l}\text { Household } \\
\text { NO3- average } \\
\text { (mg/L) }\end{array}$} & \multirow[t]{2}{*}{ No stillbirth } & \multirow[t]{2}{*}{ Stillbirth } & \multicolumn{2}{|l|}{ HR $(95 \% \mathrm{Cl})$} \\
\hline & & & Unadjusted & Adjusted $^{a}$ \\
\hline$\leq 1$ & 151,433 & 616 & 1 & 1 \\
\hline$>1-\leq 2$ & 198,781 & 713 & $\begin{array}{l}0.88(0.79- \\
0.98)\end{array}$ & $\begin{array}{l}0.97 \\
(0.80-1.18)\end{array}$ \\
\hline$>2-\leq 5$ & 214,620 & 749 & $\begin{array}{l}0.86(0.78- \\
0.96)\end{array}$ & $\begin{array}{l}0.88 \\
(0.72-1.07)\end{array}$ \\
\hline$>5-\leq 25$ & 63,221 & 240 & $\begin{array}{l}0.93(0.80- \\
1.08)\end{array}$ & $\begin{array}{l}0.95 \\
(0.73-1.24)\end{array}$ \\
\hline$>25$ & 22,344 & 93 & $\begin{array}{l}1.01(0.81- \\
1.26)\end{array}$ & $\begin{array}{l}1.26 \\
(0.89-1.79)\end{array}$ \\
\hline
\end{tabular}

${ }^{a}$ Adjusted for parity, urbanicity and maternal age, body mass index, smoking, education and occupation the drugs. However, as patients have to pay a portion of the cost of their redeemed prescriptions, our estimates likely reflect actual drug intake. An additional concern is use of over-the-counter nitrosatable drugs because these are not covered by registry data. However, intake of over-the-counter drugs would result in misclassification of exposed as unexposed and likely bias our findings to the null. We only included drugs according to ATC codes independent of administration route. Topical applied drugs such as nicotine replacement will not lead to formation of NOCs as in the acidic environment in the stomach which would lead to misclassification of unexposed as exposed and likely further bias our findings to the null.

Furthermore, although our classification of nitrosatable drugs is based on the most extensive reviews and up-to-date resources available, there is still the possibility that some nitrosatable drugs have been missed as the

Table 3 Hazard ratios (HRs) for stillbirth given any nitrosatable prescription drug intake during the first 22 weeks of pregnancy by levels of maternal drinking water nitrate concentration

\begin{tabular}{|c|c|c|c|c|c|}
\hline \multirow{2}{*}{$\begin{array}{l}\text { Household NO3- } \\
\text { average (mg/L) }\end{array}$} & \multirow{2}{*}{$\begin{array}{l}\text { Any nitrosatable prescription drug intake } \\
\text { during the first } 22 \text { weeks of pregnancy }\end{array}$} & \multirow[t]{2}{*}{ No stillbirth } & \multirow[t]{2}{*}{ Stillbirth } & \multicolumn{2}{|l|}{ HR $(95 \% \mathrm{Cl})$} \\
\hline & & & & Unadjusted & Adjusted $^{a}$ \\
\hline \multirow[t]{2}{*}{$\leq 1$} & No & 127,695 & 518 & 1 & 1 \\
\hline & Yes & 23,738 & 98 & $1.03(0.83-1.28)$ & $0.89(0.61-1.30)$ \\
\hline \multirow[t]{2}{*}{$>1-\leq 2$} & No & 170,289 & 581 & 1 & 1 \\
\hline & Yes & 28,492 & 132 & $1.38(1.14-1.67)$ & $1.55(1.15-2.09)$ \\
\hline \multirow[t]{2}{*}{$>2-\leq 5$} & No & 181,243 & 625 & 1 & 1 \\
\hline & Yes & 33,377 & 124 & $1.10(0.91-1.34)$ & $1.20(0.87-1.66)$ \\
\hline \multirow[t]{2}{*}{$>5-\leq 25$} & No & 52,442 & 192 & 1 & 1 \\
\hline & Yes & 10,779 & 48 & $1.24(0.91-1.70)$ & $1.32(0.73-2.37)$ \\
\hline \multirow[t]{2}{*}{$>25$} & No & 18,904 & 77 & 1 & 1 \\
\hline & Yes & 3440 & 16 & $1.17(0.68-2.01)$ & $1.32(0.60-2.90)$ \\
\hline
\end{tabular}

${ }^{a}$ Adjusted for parity, urbanicity and maternal age, body mass index, smoking, education and occupation 
Table 4 Hazard ratios (HRs) for stillbirth given prescriptions with secondary amine(s), tertiary amine(s) or amide(s) during the first 22 weeks of pregnancy by levels of maternal household drinking water nitrate concentration

\begin{tabular}{|c|c|c|c|c|c|}
\hline \multirow[t]{2}{*}{ Household NO3- average (mg/L) } & \multirow{2}{*}{$\begin{array}{l}\text { Secondary amine intake during the first } 22 \text { weeks of } \\
\text { pregnancy }\end{array}$} & \multirow[t]{2}{*}{ No stillbirth } & \multirow[t]{2}{*}{ Stillbirth } & \multicolumn{2}{|l|}{$\mathrm{HR}(95 \% \mathrm{Cl})$} \\
\hline & & & & Unadjusted & Adjusted $^{a}$ \\
\hline \multirow[t]{2}{*}{$\leq 1$} & No & 146,486 & 594 & 1 & 1 \\
\hline & Yes & 4947 & 22 & $1.12(0.74-1.72)$ & $1.22(0.64-2.30)$ \\
\hline \multirow[t]{2}{*}{$>1-\leq 2$} & No & 192,737 & 682 & 1 & 1 \\
\hline & Yes & 6044 & 31 & $1.50(1.05-2.15)$ & $1.39(0.78-2.49)$ \\
\hline \multirow{2}{*}{$>2-\leq 5$} & No & 207,954 & 723 & 1 & 1 \\
\hline & Yes & 6666 & 26 & $1.16(0.78-1.72)$ & $1.20(0.65-2.20)$ \\
\hline \multirow[t]{2}{*}{$>5-\leq 25$} & No & 61,126 & 234 & 1 & 1 \\
\hline & Yes & 2095 & 6 & $0.78(0.35-1.76)$ & $0.38(0.05-2.76)$ \\
\hline \multirow[t]{2}{*}{$>25$} & No & 21,700 & 87 & 1 & 1 \\
\hline & Yes & 644 & 6 & $2.36(1.03-5.40)$ & $3.11(1.08-8.94)$ \\
\hline \multirow[t]{2}{*}{ Household NO3- average (mg/L) } & \multirow{2}{*}{$\begin{array}{l}\text { Tertiary amine intake during the first } 22 \text { weeks of preg- } \\
\text { nancy }\end{array}$} & \multirow[t]{2}{*}{ No stillbirth } & \multirow{2}{*}{ Stillbirth } & $\mathrm{HR}(95 \% \mathrm{Cl})$ & \\
\hline & & & & Unadjusted & Adjusted $^{a}$ \\
\hline \multirow[t]{2}{*}{$\leq 1$} & No & 141,881 & 583 & 1 & 1 \\
\hline & Yes & 9552 & 33 & $0.85(0.60-1.21)$ & $0.55(0.27-1.12)$ \\
\hline \multirow[t]{2}{*}{$>1-\leq 2$} & No & 187,809 & 668 & 1 & 1 \\
\hline & Yes & 10,972 & 45 & $1.18(0.87-1.59)$ & $1.79(1.18-2.69)$ \\
\hline \multirow[t]{2}{*}{$>2-\leq 5$} & No & 201,622 & 700 & 1 & 1 \\
\hline & Yes & 12,998 & 49 & $1.11(0.83-1.49)$ & $1.34(0.85-2.12)$ \\
\hline \multirow[t]{2}{*}{$>5-\leq 25$} & No & 58,941 & 221 & 1 & 1 \\
\hline & Yes & 4280 & 19 & $1.21(0.76-1.94)$ & $1.61(0.74-3.53)$ \\
\hline \multirow[t]{2}{*}{$>25$} & No & 20,950 & 87 & 1 & 1 \\
\hline & Yes & 1394 & 6 & $1.07(0.47-2.44)$ & $1.54(0.54-4.35)$ \\
\hline \multirow[t]{2}{*}{ Household NO3- average (mg/L) } & Amide intake during the first 22 weeks of pregnancy & No stillbirth & Stillbirth & $\operatorname{HR}(95 \% \mathrm{Cl})$ & \\
\hline & & & & Unadjusted & Adjusted $^{a}$ \\
\hline \multirow[t]{2}{*}{$\leq 1$} & No & 134,846 & 550 & 1 & 1 \\
\hline & Yes & 16,587 & 66 & $0.98(0.76-1.27)$ & $0.79(0.50-1.27)$ \\
\hline \multirow[t]{2}{*}{$>1-\leq 2$} & No & 178,988 & 622 & 1 & 1 \\
\hline & Yes & 19,793 & 91 & $1.34(1.08-1.67)$ & $1.45(1.02-2.06)$ \\
\hline \multirow[t]{2}{*}{$>2-\leq 5$} & No & 191,278 & 668 & 1 & 1 \\
\hline & Yes & 23,342 & 81 & $1.01(0.80-1.27)$ & $1.07(0.72-1.59)$ \\
\hline \multirow[t]{2}{*}{$>5-\leq 25$} & No & 55,633 & 202 & 1 & 1 \\
\hline & Yes & 7588 & 38 & $1.40(0.99-1.98)$ & $1.50(0.79-2.86)$ \\
\hline \multirow[t]{2}{*}{$>25$} & No & 19,854 & 83 & 1 & 1 \\
\hline & Yes & 2490 & 10 & $0.98(0.51-1.90)$ & $0.90(0.32-2.54)$ \\
\hline
\end{tabular}

${ }^{\text {a }}$ Adjusted for parity, urbanicity and maternal age, body mass index, smoking, education and occupation

components have not been tested for the formation of genotoxic-carcinogenic $N$-nitroso derivatives.

Moreover, nitrosamine impurities have been found in drugs such as Valsartan and Varenicline (https://www. fda.gov/drugs/drug-safety-and-availability/informationabout-nitrosamine-impurities-medications, https://www. ema.europa.eu/en/human-regulatory/post-authorisat ion/referral-procedures/nitrosamine-impurities). However, we did not include these drugs in our exposure, because of the low level of nitrosamines concentrations. These drugs are not classified as nitrosatable drugs, and we doubt that including them in the exposure would bring new insights of importance, and if we did so more drugs should also be considered.

It is expected that exposure misclassification due to consumption of bottled water could also be present. However, we do not consider this to be a large source of bias, because annual bottled water consumption in Denmark is among the lowest in Europe ( $\sim 26 \mathrm{~L}$ per person) [40]. We were not able to quantify the amount of water a woman consumed and therefore assumed equivalent consumption for all pregnancies. 
Confounding by indication is of concern, as in most non-randomized observational studies. Drugs are prescribed for a medical purpose, and the estimated association could be caused by this underlying condition rather than the drug. We presume however, that if this bias was a major problem, we would have observed variation in associations by drug type according to their functional groups, which we did not. We found similar increased risk for all nitrosatable drug types and the variation in magnitude of the risk between functional groups was small. We did adjust for confounders available from the Danish registries including maternal age, parity, and lifestyle factors; however, we had no information on maternal infections and comorbidities, and therefore residual confounding is possible.

We also did not have information on individual dietary sources of $\mathrm{NO}_{3}^{-}$and $\mathrm{NO}_{2}^{-}$(i.e. green vegetables and processed meat), antioxidant supplementation, or vitamin C. Processed red meat products, may also contain low preformed NOCs [41]. However, while high drinking water $\mathrm{NO}_{3}{ }^{-}$is consistently associated with endogenous capacity, dietary $\mathrm{NO}_{3}{ }^{-}$is less likely to increase nitrosation due to the presence of nitrosation inhibitors such as polyphenols and vitamin $C$ in vegetables, which are the largest contributor to dietary $\mathrm{NO}_{3}{ }^{-}$intake $[42,43]$. Further, dietary factors vary by socioeconomic status and by urbanicity. To partly control for $\mathrm{NO}_{3}{ }^{-}$intake from dietary sources, we adjusted for maternal education and occupation and urbanicity in the analyses.

Our study had several strengths, including individuallevel estimates of $\mathrm{NO}_{3}{ }^{-}$in maternal drinking water based on measurements performed by certified laboratories. We were able to obtain and link these measurements even as maternal residence changed throughout pregnancy instead of relying on residence at birth. We had a large population and used longitudinal register data, thereby reducing the risk of selection bias and eliminating the risk of recall bias; information on nitrosatable drug exposure was recorded before and independently of the outcome. The classification of stillbirth was based on registry data, with records for inpatient and outpatient treatment in a free of charge antenatal program, which almost all Danish pregnant women take part in [44].

\section{Conclusions}

Drinking water $\mathrm{NO}^{3-}$ was not associated with risk of stillbirth, however, we found some evidence that the association between prenatal nitrosatable prescription drug intake and the risk of stillbirth may depend on the level of $\mathrm{NO}^{3-}$ in household drinking water. As nitrosatable prescription drug intake is common during pregnancy and the contamination of groundwater by $\mathrm{NO}_{3}{ }^{-}$is ubiquitous, it may be important to consider levels of drinking water $\mathrm{NO}_{3}{ }^{-}$, when examining the effect of nitrosatable drug exposure on the risk of perinatal outcomes. Large multicenter studies examining fetal death should be conducted in order to make recommendations to prescribers and regulators.

\section{Abbreviations \\ $\mathrm{NO}_{3}^{-}$: Nitrate; $\mathrm{NO}_{2}^{-}$: Nitrite; $\mathrm{NOCs}$ : N-nitroso compounds; Cls: Confidence intervals (Cls); HRs: Hazard ratios; aHRs: Adjusted hazard ratios.}

\section{Supplementary Information}

The online version contains supplementary material available at https://doi. org/10.1186/s12940-021-00805-z.

Additional file 1 : Table S1. List of included nitrosatable drugs with Anatomical Therapeutic Chemical (ATC) codes.

Acknowledgements

Not applicable.

Authors' contributions

Thomsen had full permission to all the data in the study and takes responsibility for the integrity of the data and the accuracy of the data analysis. Concept and design: Thomsen, Olsen, and Liew. Acquisition, analysis, or interpretation of data: Thomsen, Schullehner, Olsen, Ramlau-Hansen, Ebdrup, Liew, and Coffman. Drafting the manuscript: Thomsen, Olsen, Ramlau-Hansen, Coffman and Ebdrup. Critical revision of the manuscript for important intellectual content: All authors. Statistical analysis: Thomsen and Schullehner. Obtained funding: Olsen and Liew. Administrative, technical, or material support: Ramlau-Hansen and Schullehner. Supervision: Olsen, Ramlau-Hansen, Schullehner, and Liew.

The author(s) read and approved the final manuscript.

\section{Funding}

This work was supported by the Augustinus Foundation [16-3538] and BERTHA - the Danish Big Data Centre for Environment and Health funded by the Novo Nordisk Foundation Challenge Program (grant NNF170C0027864.The founding sources had no role in the design and conduct of the study.

\section{Availability of data and materials}

The analyses for this study were performed at Statistics Denmark within a strict privacy rules where only researchers who received a signed permit were allowed to do analyses within a secured environment.

\section{Declarations}

Ethics approval and consent to participate

In Denmark, the Act on Processing of Personal Data does not require ethical committee permission or obtained consent for anonymized register studies on existing data. The present study was registered at Aarhus University's Data Inventory (2020-051-000001-1897).

\section{Consent for publication}

All the authors have reviewed and approved the manuscript for publication.

\section{Competing interests}

The authors declare no conflict of interest.

\section{Author details}

${ }^{1}$ DEFACTUM, Public Health \& Health Services Research, Central Denmark Region, Olof Palmes Allé 15, 8200 Aarhus N, Denmark. ${ }^{2}$ Department of Public Health, Aarhus University, Aarhus, Denmark. ${ }^{3}$ Department of Groundwater and Quaternary Geology Mapping, Geological Survey of Denmark and Greenland, Aarhus, Denmark. ${ }^{4}$ Center for Integrated Research-based Research, Aarhus University, Aarhus, Denmark. ${ }^{5}$ Department of Environmental Health 
Sciences, Yale School of Public Health, New Haven, CT, USA. ${ }^{6}$ Yale Center for Perinatal, Pediatric, and Environmental Epidemiology, Yale School of Public Health, New Haven, USA. ${ }^{7}$ Division of Epidemiology and Biostatistics, School of Public Health, University of Illinois at Chicago, Chicago, IL, USA. ${ }^{8}$ Department of Clinical Epidemiology, Aarhus University Hospital, Aarhus, Denmark.

Received: 18 August 2021 Accepted: 8 November 2021 Published online: 16 November 2021

\section{References}

1. Brender JD, Kelley KE, Werler MM, Langlois PH, Suarez L, Canfield MA. National Birth Defects Prevention Study. Prevalence and patterns of nitrosatable drug use among U.S. women during early pregnancy. Birth Defects Res A Clin Mol Teratol. 2011;91:258-64.

2. Thomsen AML, Liew Z, Riis AH, Stayner LT, Ramlau-Hansen $\mathrm{CH}$, Sigsgaard T, et al. Nitrosatable drug exposure during pregnancy and risk of stillbirth. Pharmacoepidemiol Drug Saf. 2019;28:1204-10.

3. Lijinsky W. Reaction of drugs with nitrous acid as a source of carcinogenic nitrosamines. Cancer Res. 1974;34:255-8.

4. Brambilla G, Martelli A. Genotoxic and carcinogenic risk to humans of drug-nitrite interaction products. Mutat Res. 2007;635:17-52.

5. Dietrich M, Block G, Pogoda JM, Buffler P, Hecht S, Preston-Martin S. A review: dietary and endogenously formed N-nitroso compounds and risk of childhood brain tumors. Cancer Causes Control. 2005;16:619-35.

6. Mirvish SS. Role of N-nitroso compounds (NOC) and N-nitrosation in etiology of gastric, esophageal, nasopharyngeal and bladder cancer and contribution to cancer of known exposures to NOC. Cancer Lett. 1995;93:17-48.

7. Fan AM, Steinberg VE. Health implications of nitrate and nitrite in drinking water: an update on methemoglobinemia occurrence and reproductive and developmental toxicity. Regul Toxicol Pharmacol. 1996;23:35-43.

8. Bochert G, PlatzekT, Blankenburg G, Wiessler M, Neubert D. Embryotoxicity induced by alkylating agents: left-sided preponderance of paw malformations induced by acetoxymethyl-methylnitrosamine in mice. Arch Toxicol. 1985;56:139-50.

9. Brender JD, Werler MM, Kelley KE, Vuong AM, Shinde MU, Zheng Q, et al. Nitrosatable drug exposure during early pregnancy and neural tube defects in offspring: National Birth Defects Prevention Study. Am J Epidemiol. 2011;174:1286-95.

10. Benedum CM, Yazdy MM, Mitchell AA, Werler MM. Impact of Periconceptional use of nitrosatable drugs on the risk of neural tube defects. Am J Epidemiol. 2015;182:675-84.

11. Brender JD, Werler MM, Shinde MU, Vuong AM, Kelley KE, Huber JC Jr, et al. National Birth Defects Prevention Study. Nitrosatable drug exposure during the first trimester of pregnancy and selected congenital malformations. Birth Defects Res A Clin Mol Teratol. 2012;94:701-13.

12. Vuong AM, Shinde MU, Brender JD, Shipp EM, Huber JC Jr, Zheng Q, et al. National Birth Defects Prevention Study. Nitrosatable drug exposure during pregnancy and preterm and small-for-gestational-age births. Paediatr Perinat Epidemiol. 2015;29:60-71.

13. Olshan AF, Faustman EM. Nitrosatable drug exposure during pregnancy and adverse pregnancy outcome. Int J Epidemiol. 1989;18:891-9.

14. Lawn JE, Blencowe H, Waiswa P, Amouzou A, Mathers C, Hogan D, et al. Stillbirths: rates, risk factors, and acceleration towards 2030. Lancet. 2016;387:587-603.

15. Cousens S, Blencowe H, Stanton C, Chou D, Ahmed S, Steinhardt L, et al. National, regional, and worldwide estimates of stillbirth rates in 2009 with trends since 1995: a systematic analysis. Lancet. 2011;377:1319-30.

16. Flenady V, Middleton P, Smith GC, Duke W, Erwich JJ, Khong TY, et al. Stillbirths: the way forward in high-income countries. Lancet. 2011;377:1703-17.

17. Flenady V, Koopmans L, Middleton P, Frøen JF, Smith GC, Gibbons K, et al. Major risk factors for stillbirth in high-income countries: a systematic review and meta-analysis. Lancet. 2011;377:1331-40.

18. Smith GC, Fretts RC. Stillbirth Lancet. 2007;370:1715-25.

19. Stillbirth Collaborative Research Network Writing Group. Causes of death among stillbirths. JAMA. 2011;306:2459-68.
20. Hansen B, Thorling L, Dalgaard T, Erlandsen M. Trend reversal of nitrate in Danish groundwater--a reflection of agricultural practices and nitrogen surpluses since 1950. Environ Sci Technol. 2011;45:228-34.

21. Schullehner J, Hansen B. Nitrate exposure from drinking water in Denmark over the last 35 years. Environ Res Lett. 2014. https://doi.org/ 10.1088/1748-9326/9/9/095001.

22. WHO. Nitrate and nitrite in drinking-water: background document for development of WHO guidelines for drinking-water quality. Geneva: World Health Organization; 2011. Available from: https://www.who.int/ water_sanitation_health/dwq/chemicals/nitrate-nitrite-backgroundjan17.pdf

23. Ward MH, deKok TM, Levallois P, Brender J, Gulis G, Nolan BT, et al. Workgroup report: drinking-water nitrate and health--recent findings and research needs. Environ Health Perspect. 2005;113:1607-14.

24. Ward MH, Jones RR, Brender JD, de Kok TM, Weyer PJ, Nolan BT, et al. Drinking water nitrate and human health: an updated review. Int J Environ Res Public Health. 2018;15:1557.

25. Coffman VR, Jensen AS, Trabjerg BB, Pedersen CB, Hansen B, Sigsgaard $T$, et al. Prenatal exposure to nitrate from drinking water and markers of fetal growth restriction: a population-based study of nearly one million Danish-born children. Environ Health Perspect. 2021;129:27002.

26. Stayner LT, Almberg K, Jones R, Graber J, Pedersen M, Turyk M. Atrazine and nitrate in drinking water and the risk of preterm delivery and low birth weight in four Midwestern states. Environ Res. 2017;152:294-303.

27. Pedersen CB, Gøtzsche H, Møller JO, Mortensen PB. The Danish civil registration system. A cohort of eight million persons. Dan Med Bull. 2006;53:441-9.

28. Knudsen LB, Olsen J. The Danish medical birth registry. Dan Med Bull. 1998;45:320-3.

29. Kildemoes HW, Sørensen HT, Hallas J. The Danish National Prescription Registry. Scand J Public Health. 2011;39(Suppl 7):38-41.

30. Sørensen HT, Hansen I, Ejlersen E, Sabroe S, Hamburger H. Identification of patients treated with strong analgesics: an assessment of two Danish information systems with respect to epidemiological research. J Med Syst. 1996;20:57-65.

31. McKean-Cowdin R, Pogoda JM, Lijinsky W, Holly EA, Mueller BA, Preston-Martin S. Maternal prenatal exposure to nitrosatable drugs and childhood brain tumours. Int J Epidemiol. 2003;32:211-7.

32. Hansen M, Pjetursson B. Free, online Danish shallow geological data. Geo Survey Denmark Greenland (GEUS) Bull. 2011;23:53-6.

33. Schullehner J, Stayner L, Hansen B. Nitrate, nitrite, and ammonium variability in drinking water distribution systems. Int J Environ Res Public Health. 2017;9(14):276.

34. Schullehner J, Jensen NL, Thygesen M, Hansen B, Sigsgaard T. Drinking water nitrate estimation at household-level in Danish population-based long-term epidemiologic studies. J Geochem Explor. 2017; 183:178-86.

35. Sundhedsstyrelsen. Anbefalinger for Svangreomsorgen 2013. [Available from: http://sundhedsstyrelsen.dk/publ/Publ2013/10okt/Svang reomsorg.2013.pdf].

36. Pearl J. Causality: models, reasoning and inference. 2nd ed. Cambridge: Cambridge University Press; 2009.

37. Liew L, Olsen J, Cui X, Ritz B, Arah OA. Bias from conditioning on live birth in pregnancy cohorts: an illustration based on neurodevelopment in children after prenatal exposure to organic pollutants. Int J Epidemiol. 2015:44:345-54

38. Vuong AM, Shinde MU, Brender JD, et al. Prenatal exposure to nitrosatable drugs, dietary intake of nitrites, and preterm birth. Am J Epidemiol. 2016;183:634-42.

39. Brender JD, Olive JM, Felkner M, Suarez L, Marckwardt W, Hendricks KA. Dietary nitrites and nitrates, nitrosatable drugs, and neural tube defects. Epidemiology. 2004;15:330-6.

40. Rygaard M, Arvin E, Binning PJ. The valuation of water quality: effects of mixing different drinking water qualities. Water Res. 2009;43:1207-18.

41. Gamage SMK, Dissabandara L, Lam AK, Gopalan V. The role of heme iron molecules derived from red and processed meat in the pathogenesis of colorectal carcinoma. Crit Rev Oncol Hematol. 2018;126:121-8.

42. Habermeyer M, Roth A, Guth S, Diel P, Engel KH, Epe B, et al. Nitrate and nitrite in the diet: how to assess their benefit and risk for human health. Mol Nutr Food Res. 2015;59:106-28. 
43. Bartsch H, Ohshima H, Pignatelli B. Inhibitors of endogenous nitrosation Mechanisms and implications in human cancer prevention. Mutat Res. 1988;202:307-24.

44. Jørgensen FS. Ultrasonic examination of pregnant women in Denmark 1989-1990. Ugeskr Laeger. 1993;24(155):1627-32

\section{Publisher's Note}

Springer Nature remains neutral with regard to jurisdictional claims in published maps and institutional affiliations.
Ready to submit your research? Choose BMC and benefit from:

- fast, convenient online submission

- thorough peer review by experienced researchers in your field

- rapid publication on acceptance

- support for research data, including large and complex data types

- gold Open Access which fosters wider collaboration and increased citations

- maximum visibility for your research: over $100 \mathrm{M}$ website views per year

At BMC, research is always in progress.

Learn more biomedcentral.com/submissions 